\title{
Nation, territory, memory: making state-space meaningful
}

\author{
Anssi Paasi
}

\section{Introduction}

Geography has been in a critical position in the formation of ideas of territorially bounded homelands, nations, and its conceptual basis echoes this connection. Entrikin (2002) observes how terms such as territory, place, and landscape have been regularly connected to an atavistic ethnos rather than a more cosmopolitan demos, and how these terms often allude to primordial links of peoples to land and of blood to soil. These terms, he notes, fuse the material and the affective in often emotionalized narratives of collective identity and shared historical experience and memory. Geographers have certainly not been just marionettes in the service of nationalism. Critical scholars have studied these terms since the 1960s-70s and challenged the taken for granted 'boundedness' of spaces (Paasi, Harrison and Jones 2018). Yet, in a world where millions of immigrants and asylum seekers escape wars, hunger and ecological problems, and cross state borders to seek refuge, and where ethno-nationalist and xenophobic violence flourish, there is a grave need to analyze critically of the changing practices and discourses behind the lasting grasp of bounded territories and their roles as fuel for nationalism (cf. Murphy 2013, Meusburger et al. 2011).

Researchers have suggested that state territory is now partly 'giving up' in the globalizing world. Sassen (2009), for example, states that while the exclusive territorial authority of the state seems to remain predominant, the constitutive elements of this authority are now less absolute than 'once intended to be' and that the critical site for making and registering 
that change is not inevitably the traditional territorial border. Also 'nations' living in diaspora have today better tools to communicate across borders. Territory is also challenged by social movements such as 'no borders' that struggle against bounded territorial spaces and emphasize the need for free movement, and, in the extreme case, make anarchists claim to abandon states and nations (Paasi 2019).

And yet, territory's allure continues, not least because it is important raw-material for 'essentialist' national identity narratives (Delaney 2005; Murphy 2013). Ethno-regionalist movements around the world struggle to create their own territorial state with an identity and existing states firmly aim to regulate their integrity and borders. Yet, inside states much of what is epitomized as 'national' and that is instrumental in reproducing the nation, is not literally filling the national territory but is frequently located in places such as capital cities, for example, national museums and other 'institutions of memory', political powerhouses, and the centers of economic power such as national banks. However, identity symbols and memories are not packed merely in museums, archives or landscapes, but they are also part of everyday life. Painter (2006) maintains that 'stateness' - state as a relational territorial effect - permeates into everyday life in virtually every area of social life: birth, health care, education, work, housing, and even dying are monitored by states. Similarly territory itself is a product of social relations. The emotional side of stateness resonates with the experiences of national symbols, memorials, rituals, spectacles, novels, movies, (political) comics, habits and affects. Memory works at both individual and collective levels that nurture each other (Halbwachs 1992). Consequently state, territory and nation are articulated and become fused in abundant practices and discourses, through which the symbols, narratives and institutions of national identity are created and become part of daily life where collective forms of identity are ultimately reproduced. 
Traditions are incessantly (re-)invented and modified in memory work. Thus national memory is always contested since the past itself is disputed. Johnson (2011:241) writes that 'while social elites may attempt to galvanize power through the control of the public choreography of memory, geographers have demonstrated how subaltern groups, of various sorts, have challenged dominant renditions of the past and contested the interpretation presented through museums, memorials, heritage sites, commemorative rituals and naming practices'. Heritage embodies a medley of history that has been mobilized to craft certain visions of places and nations and this raises questions such as whose recollections and narratives regarding the past are entitled to gain voice, visibility, and a hegemony, and whose memories (and counter-memories) are silenced. Similarly questions arise on how political elites in particular struggle when deciding how appropriate recollections are selected and transformed into monuments, when choosing the places where they are situated in national space, or what artefacts, stories and 'truths' are accepted to symbolize the past (Forest and Johnson 2002; Kuzio 2002). After Civil Wars, for instance, hegemonic memorials frequently embody winner's 'histories' whereas in occupied territories subjugators often rapidly alter symbols, place names and even monuments. Radical changes also often occur after major systemic level political changes in a state, and national symbols are transformed. Hence memory and seeing the national past in specific ways have strategic, political, ethical and ideological consequences.

The chapters in this collection examine the meanings of territory/territoriality from various vantage points. The present chapter focuses on the oft-neglected relation between territory and national memory. The significance and ideological uses of memory cannot be underestimated when reflecting the manufacturing of national state territories as 'homelands'. Memories and identity narratives do not rise in vacuo. Homeland is a pool of historic memories, images, and accounts of national landscapes, heroes, past struggles 
and sacrifices recounted by intellectuals, artists, and politicians who usually play a critical role in crafting them (Mellor 1989, Smith 1991).

Territory is both constitutive of and constituted by the spatialized memories, narratives and symbols of national identities. It is therefore crucial in state- and nation-building (e.g. Johnson 1995, Storey 2018). The continuity of territories as sources of identity is largely based on spatial socialization through which 'individuals and collectivities are socialized as members of specific territorially bounded entities and through which they... internalize collective territorial identities and shared traditions' (Paasi 1996:8). Spatial socialization is a key concept for understanding how state effect works (Murphy 2013; Koch 2016). Territory is hence a dynamic, historically contingent manifestation of materiality, symbolism, emotions, memories and power (Paasi 2016).

This chapter is structured as follows. The next sections problematize the idea of territory and what it means as a social and ideological construct and process. The following section looks at territory and memory and the next one the roles of borders in the territory/memory nexus. My approach is mainly conceptual but concrete illustrations are taken from various socio-spatial contexts. Finally, conclusions will follow and some potential themes for the research agenda are suggested.

\section{The complexity of territory}

Cox (2002:2) argues that territory and territoriality are the core concepts of political geography. Their significance is based on the fact that they closely reverberate with other key categories of the field such as state, (territorial) border, power and nation(alism). Currently the state is the key institution for problematizing territory and territoriality and no 
state theory can overlook them. Yet, often territory is seen as a neutral intermediary domain where state power a§nd social relations are manifested and come together. This position does not mean that theorists have naturalized or fetishized national territories as pre-given or predestined scales of state-formation. For many scholars since Antonio Gramsci the territorialization of state-power has been 'a crucial first step in national state formation and nation-building' (Jessop 2008:112).

While the constitutive features of territories depend on the scale of analysis and the aims of the analyst, some components and practices characterize most definitions, such as land/area, borders, and the policing/governance of inclusion/exclusion (Soja 1971; Sack 1986; Storey 2012; Kolers 2009). Borders are not merely abstract dividing lines but processes and discourses where ideological, political, cultural and governmental elements converge (Paasi 2019). Likewise territorial symbols are critical for belonging, identity and memory (Gottmann 1973; Hassner 1997; Paasi 2003; Storey 2018). These features resonate with emotions and affects and are particularly important when territory and nation come together, as research on banal nationalism has demonstrated (Billig 1995, Koch and Paasi 2016). Such features are often mobilized to justify a historic homeland and a sense of a political community evolving from the territory-nation nexus (Smith 1991, Kaiser 2002). Williams and Smith (1983) argue that nationalism is always a struggle for control of land and nation is a mode of constructing and interpreting social space. They divide national territory analytically into two categories. The first, 'sociogeographical', views land and nation as primarily spatial entities, the second, 'sociopolitical', translates these into political constructs and pays particular attention to the relations between ethnic communities and their historic territories. 
The relation between state and nation is multifaceted; often these are conflated as are the processes of nation- and state-building (Yiftachel 2002, Antonsich 2009). A nation can precede or follow a state of its own but the latter can support the former to a greater selfconsciousness (Hasting 1997). Nation is also the major component for understanding the cultural, political and ideological appeal of state territories. Collective memories serve as important tools for such understanding but this is by no means any guarantee of national coherence. According to Gellner's (1983) well-known definition nationalism is a political principle, which claims that political and national units should be congruent. Contemporary world hosts some 200 states but several hundreds of social groupings identifying themselves as 'nations', which shows the elusiveness of this ideal. States may include several nations and irredentist claims stretch beyond existing state borders. This unbalanced relation between a state and potential nations is often a challenge for the imagined consistency of national identity. Such identity narratives are political and ideological constructs but frequently tend to disregard intra-state diversity and the intersectionality of class, ethnicity, gender and generational interests. National minorities and subjugated ethnic groups frequently contest the myth of a culturally homogeneous community inhabiting a state territory by promoting their own distinctive identities (Guibernau 2007).

In spite of globalization and the general opening of borders, each state aims to control its territory, borders, 'national identity' and loyalties. Examples of such control are incessantly witnessed around the world. In current European states such as Hungary or Poland, for example, state leaders aim fervently to regulate national identity narratives by mobilizing ideologies and bordering practices based on anti-immigration. In Spain, rather than explicit anti-state activities, simply presenting jokes on themes that challenge national integrity can 
bring people into jail (Jokinen 2018). Repressive state violence is currently used also to regulate the Catalans' struggle for national independence. These are signs of a broader question: why do some states disintegrate, often along ethnic lines, while others are held together over long periods, decades and centuries, even if the inhabitants may be diverse (Wimmer 2018). Therefore national memory and understanding of the past are not innocent. Struggles over the past are also fights over the present and the future of a territory (Hodgkin and Radstone 2012). Correspondingly political integration and national identification form two sides of the same 'nation-building coin' (Wimmer 2018).

\section{Territories as social and ideological constructs}

Territories are nowadays regarded as 'social constructs', but it is often unclear how this should be understood. Social constructionism is a popular approach in social sciences, in nationalism research and studies on 'imagined communities' that focus on identity-building (Yiftachel 2002). Ochoa Espejo (2018, p. 77) notes how '...the social-constructivist approach is shared by nationalists, who often value the outcomes of historical processes, by Marxists who want to change them, and by genealogists who question their permanence and thus, the relevance of these processes'. Accordingly social reality, identities and meanings are constructed in contested social and linguistic interaction.

Social constructionism often highlights the end products of such construction but can also point towards the process of constructing something (Hacking 1999). In political geography territories are frequently seen as existing end products, which perhaps explains why they are often taken for granted as spatial settings where social processes occur. Knight (1982, p. 517) has noted that 'territory is not; it becomes, for territory itself is passive, and it is 
human beliefs and actions that give territory meaning.' Whether 'territory' is passive or not, depends clearly on our conceptualization of this term. A more productive approach to state territories is to conceptualize them as social processes that become gradually institutionalized in complex institutional processes and discourses but that may also deinstitutionalize, be divided into new, smaller territories or be unified into larger, suprastate level political entities (Paasi 2016). This occurs either peacefully or, more likely, through conflicts that arise from the changing power relations between the state and nation(s) or ethnic groupings. Think, for example, the breakdown of the former Soviet Union, Yugoslavia or African states Somalia and Sudan and the resulting rise of new territorial spaces. The institutionalization of new state territories will without doubt continue also in the future since tens of ethno-nationalist groupings around the world identify themselves as nations on ethnic, linguistic, or religious grounds. Such efforts usually display separation or integration nationalism where nations struggle to achieve an autonomous or independent territorial statehood, and relevant governmental and cultural institutions (Taylor and Flint 2000: 203-206).

Wars and conflicts may lead to rapid changes in territorial borders and quickly remove territorial states as political structures from the world map but this does not inevitably take place so rapidly for nations and their often deeply embedded national symbols, memories and ideologies. Of course, ethnic cleansing often bluntly aims at such removal. Following from deinstitutionalization, sometimes people stay in occupied territories and become national minorities in new states. At times they become refugees and move to other states or what is left of the old state territory, like the 400.000 Karelians who left after World War II their home region occupied by the Soviet Union and resettled elsewhere in the remaining Finnish territory. Memories of lost territories and exile are often traumatic and can 
encompass several successive generations (Paasi 1996, 2016). Different kind of examples are the Estonia and Lithuania that became once again independent after the breakup of the Soviet Union, which left large Russian ethnic minorities in these state territories.

In spite of the common tendency of national history writing and folklore to invent and justify traditions and to create continuity towards the past, most sovereign states are young. Political historians often trace the birth of territorial state to the $16^{\text {th }}-17^{\text {th }}$ centuries. Mann (1996:296) argues that prior to eighteenth century states did very little but monopolized military violence. Military function expanded in the $18^{\text {th }}$ century but in real sociological terms, territorial state's sovereignty has emerged lately and matured even more recently. During the $18^{\text {th }}$ century 'states were becoming cages, trapping subjects within their bars', writes Mann. This gradually activated ordinary people to claim changes in the conditions of 'cages', to demand political citizenship and to express emerging nationalist ideologies. States also gradually shaped infrastructures, such as communication and education systems that became key elements in constructing nations as imagined communities (Mann 1996, Anderson 1991). The circulation of newspapers and books played a critical role in inspiring nationalism that fostered autonomy and independence movements around the world. Yet, Mann (1996) notes, the emergence of social citizenship took place only at the beginning of the $20^{\text {th }}$ century and the first true 'nation-states' developed.

An important question is how state territory becomes part of national identities/ideologies. The existence of a territory is an elementary assumption in nationalism literature (Williams and Smith 1983; Smith 1991). Since 'nations are not things that exist in the world independently of the beliefs people have about them' (Miller 1995:17), another critical question is how the territory and narratives of national identity become part of the daily lives of citizens. Much of national belonging occurs through 'practical consciousness' 
(Giddens1984). People rarely need to reflect discursively their belonging to a nation; various forms of banal nationalism simply 'envelope' people their daily life and may condensate during the periods of international conflicts. Nationality formally becomes materialized through citizenship - a state bound category - in ordinary geographies of stateness (Painter 2006). National belonging is constructed as part of these geographies in spatial socialization. Geographic and cartographic education provides the outlines for a shared understanding of territories, while history often provides historical depth, knowledge and attitudes towards selected, germane national events and memories (Paasi 1996). However, it is not only teaching specific subjects that matter but also educational practices more generally. In the USA, for example, in 25 states children start their school day with A Pledge of Allegiance: 'I pledge allegiance to the Flag of the United States of America, and to the Republic for which it stands, one Nation under God, indivisible, with liberty and justice for all.' Such a fusion of the nation and religion is an essential component in contemporary nationalisms around the world.

Nationalism is the most territorial of all ideologies and it legitimates selected identity narratives by tracing them back to real, imaginary and memorialized past; territory is sustained by ideological tools. Ironically national identity is routinely appreciated as a constructive phenomenon whereas nationalism is seen as destructive, even if they are two sides of the same coin and nourish each other. Ideologies are social structures that are always to some extend 'given' to human agents even if they are more or less actively involved in their reproduction and modification. Giddens' (1984) ideas are beneficial for understanding how 'structures' works. For him structure means rules and resources that are recursively implicated in the reproduction of social systems. Structure exists as memory traces - the organic basis of human knowledgeability - and is instantiated in 
action. Structure thus take shape both internally within agents as memory traces and externally as expressions of social action.

National identity, particularly when it is articulated and reminisced by the 'official states', therefore resonates closely with ideology. Ideology is thus not merely a set of ideas or beliefs but rather a complicated set of intertwined social practices and discourses that manifest themselves in interaction with institutions such as religion, the family, the judiciary, the political system and parties, communication (the media) and culture, for instance, literature, art, or sport. These elements have been labelled broadly as the 'ideological state apparatus' (Althusser 1983). The state also effectively regulates education and language. The power of language is in its ability to generate accepted wisdoms regarding the national community whereas the power of education is in its capacity to regulate, modify and reproduce such wisdoms. Ideologies regularly draw on rhetorical structures and their key purpose is to persuade and convince people. Respectively they must appeal to people's future prospects and encompass a promise of something better (Gellner 1998). Even though ideologies are structures, they are not purely deterministic. Further, if ideologies are going to have an effect, they must be meaningful for actors and be reproduced by them (cf. Bloom 1990). Actors thus need identical 'national' categories for observation and action, and spatial socialization and memory are critical in inculcating them.

\section{Territory and memory}

Public memory operates through socio-cultural processes and artefacts that come into being as material representations that are recognized as symbols of a nation. Halbwachs 
(1992) suggests that every collective memory requires the support of a group delimited in space and time. For him collective memory is a construction of the past in the light of the present. Capability to remember and symbolize is critical for the continuity of a (national) territory, and for the production and reproduction of national imagined communities. Halbwachs was interested in how certain contexts and social institutions rendered possible some memories, encouraging specific recollections while discouraging some others (cf. Legg 2005). For Hobsbawm (1983) several innovations were critical in what he called as the 'invention of traditions', among them the establishment of basic education, creation of public ceremonies and the 'mass production' of public monuments that were needed in the formation of communal thinking and group identity, and which produced and transferred 'traditions'. 'Invented tradition' means for him 'a set of practices, normally governed by overtly or tacitly accepted rules and of a ritual or symbolic nature, which seek to inculcate certain values and norms of behaviour by repetition, which automatically implies continuity with the past. In fact, where possible, they normally attempt to establish continuity with a suitable historic past' (p. 1) Invented traditions are highly important not only for the 'nation', but also with its associated phenomena: nationalism, the nation-state, national symbols and histories (p. 13). Further, a nation is not only a community of shared memory but also shared forgetting (Ashuri 2005:439).

Memory and commemorations have become important objects in cultural and political geographic studies, often focusing on place-based symbolic landscapes mobilized in national identity narratives, monuments, and individual and collective experiences of the contested past (Meusburger et al. 2011). One of early works was Johnson's (1995) study of monuments that had been, she observed, an underutilized resource in geographic research on national identity. In the 1990s memory studies began to mushroom. Till and Kuusisto-Arponen (2015:293-294) identify two overlapping strands of research. Firstly, 
geographers have scrutinized the contested nature of memory and how groups and individuals struggle on who is allowed to represent their version of the past in public spaces (built environment, media, laws, spaces of belonging). Secondly, geographers have studied the translocal and transgenerational nature of memory, especially in instances of traumas. Since the turn of the millennium 'place memory' has gained more room in research (Hodgkin and Radstone 2012), often in the context of war, conflict and suffering (Drozdzewski et al. 2016).

The connection between state territory and memory is often neglected or read through intermediating categories like national identity. Some major volumes on the evolution of the territory concept do not reflect the role of memory (e.g. Sack 1986; Elden 2013), while some scholars see memory as a powerful element in the meaning making related to (state) territories (Paasi 1996, Storey 2012, 2018). Territory forges the links between nation and state and memory is effectively mobilized in efforts to create such links in selected localities that become symbols of the territory. The power of state is critical here since it is the key institution that claims the legitimate authority over territory and uses various forms of state power to do this (Miller 1995:25). Memory is also critical in efforts to create an imagined continuity to national communities and to understand how social structures, actors and agency come into play.

Territory and memory can come together in experiences mediated not only by the state, but in narratives and legends related to family histories and experiences that may join members across generations inside one family and also extent these experiences to more extensive social networks (Paasi 1996). Such mediation is also typical in societies that explicitly focus on producing and maintaining collective memories. Good examples, beyond normal institutions of socialization such as education, family and media, are 
veteran organizations (Figure 1) that maintain and perform repeatedly the memories of wars and collective sacrifice. Such organizations are responsible for mediating selective, patriotic stories and memories rather than 'whole stories'. Deserting the mental problems and post-traumatic reactions of Finnish soldiers during and after World War II are gloomy examples. During the war time soldiers with broken minds faced ignominy and condemnation, and later this phenomenon was largely silenced. Only recently psychohistorians have focused on this widespread but silenced phenomenon (Kivimäki 2013).

A far more formal layer are memories mediated in spatial socialization that provide a 'spatial shape' for elements of state space that is borders, landscapes, sub-regions, cities, or regional structures. Such shapes and their meanings vary dramatically in different contexts. Borders, for example, may have very dissimilar meanings in different states and even individual borders in one state can have radically different meanings at various times. Think, for example, the US-Mexico and US-Canada borders or the Finnish-Swedish and Finnish-Russian borders. Spatial socialization occurs in specific institutional and ideological practices. Hence territory 'must be seen in terms of the dynamic relationship existing between an area and the social processes and ideologies that give it meaning' (Murphy 1990: 532). Murphy accentuates particularly the roles of language and ideology in the making of social reality; ideology operates through language and language is a medium of social action.

Various forms of nationalism are significant in this process. Billig's (1995) work was critical in recognizing the prosaic or banal forms of nationalism and how the nation is 'flagged' in everyday lives (Koch and Paasi 2016). He argued that instead of just assuming the existence of essentialist national identities it is critical to map what people mean when talking about national identity. A case study of the Finnish nation and state-building 
processes exposed that the study of banal nationalism should not focus just on national representations or material culture. An interesting question is, how such representations become institutionalized forms of identity discourse, that is, how national ideals will permeate such institutions as education, media, national defense, sport, or religion and how they reproduce the forms of territoriality and power that are structured in the very existence of these institutions (Paasi 1996). It is typical that such institutions exist simultaneously so that media is in a decisive position in giving a nationalist or territorializing shape, for example, to sport events or national defense rhetoric (Tervo 2002). Koch (2012) shows how particularly authoritarian regimes have long taken an interest in promoting elite and mass sport, using this as both a nation-building strategy and an instrument to elicit respect and legitimacy on the global stage. Currently an important new feature in the denationalization of international sport scene are athletes who are allowed to rapidly change their nationality, even their name and use this fast track to represent their new nationality in the supposed competition between nations (Poli 2007).

One important ideological instrument and medium of spatial socialization that fuses national identity, masculine culture, memories of the past and religion, is the military institution. Compulsory military service still exists globally in more than 50 states and only five states do not have armed forces. Many European states have given up the compulsory service after the Cold War period. In 1990s 23 of EU's present member states had a compulsory service but currently only five states: Estonia, Finland, Greece, Denmark, and Austria. Military Oath often draws heavily on religious elements and claims for honor, conscience, trustful citizenship, patria, loyalty to legal state order and legal authority (Paasi 1999). Whether a state has a conscription or not, military power and related memories are highly important in banal nationalism and are mobilized in National Day and Independence Day celebration and parades, for example. The latter are often 
muscular, masculine exhibitions of military force, heroism and/or memories of collective sufferings and sacrifice (Paasi 2016). All this occurs, Smith (1991, p. 9) suggests, to celebrate a clearly demarcated and bounded territory, homeland, with which the members are expected to identify themselves, and to feel to belong.

Circumstances where political freedom or independence is attained once again after a long period of occupation, provides often a strong justification for a search for novel ways to remember the past. A fitting illustration is the Museum of Occupation in Tallinn, Estonia, where the period of Soviet occupation is reminisced in very impressive and emotional ways (Figure 2). Similarly in Finland that remained independent after World War II but was forced to cede ten percent of its land area to Soviet Union, national landscapes and Independence Day celebrations are permeated with the imaginings of war and sacrifice and not just images of an imagined past that can be found in national epics or landscapes. The military element of such celebrations has expanded after the collapse of the Soviet Union (Paasi 2016).

An important constituent of national identities and nationalized historical memory are enemy images or images of the Other based on historical events or myths, on experienced injustices, or stereotypes that may be empty, racialized generalizations or include some historical kernel of truth. A long-term example such images is the building of the Finnish nation and state where Russia/Soviet Union was regarded as an eternal enemy after Finland gained her independence in 1917. Negative depictions also became institutionalized in national socialization but largely disappeared again after World War II when Finland lost the war to the Soviet Union and outlined a new cautious foreign policy (Paasi 1996). Soon after gaining the independence the nation itself was deeply divided. A Civil War bursted in Finland between the White and Red factions where the former was 
supported by German troops and the latter by the Soviet-Russia. The Whites lost over 5000 people and the Reds more than 30000 people in Civil War and in camps that were established after the war. This episode give rise to a trauma in the collective memory that also manifested itself in the divided concrete landscape in the form of separate memorials and cemeteries for White and Red sides (Fig. 3). Civil War itself was also termed in various ways as a civil war, war between brothers, freedom war, or a national war, depending on the political predispositions of the presenter.

Another example is provided by the Soviet Union/Russia. During the Soviet period socialist iconography was almost omnipresent in that state. For example, in over 100 places altogether more than 500 buildings were linked to the memory of Lenin and his statues were present all over the Soviet state (Kislik 1983) as well as elsewhere in the socialist Eastern Europe. In the contemporary Russia, the Soviet heritage and memorials are still significant part of memorial places and landscapes and they exist in parallel with the grandiose monuments that highlight ethnic and imperial conceptions of Russian identity. The capital city Moscow is impregnated with socialist symbolism that has become an important part of cultural heritage. During Putin's period Lenin and Stalin have experienced a symbolic renaissance and the old Soviet national anthem (with new words), for example, has been restored (Forest and Johnson 2002). Contrary to this, in many former socialist states, such as Poland, Lithuania, Hungary or Georgia, such symbolism has been forcefully rejected. In Georgia Freedom Charter accepted in 2011 requires the removal of the symbols of the communist era, such as place names, memorials, or buildings (Paasi 2013).

Memories can also be associated literally with a 'collective' national body that is converted into a representation of a nation. The legendary Finnish long-distance runner Paavo 
Nurmi, the winner of nine Olympic gold medals in 1920-1928, has been said to have run Finland literally on the world map (Tervo 2002). It is not always only real bodies through which collective memories are energized. In numerous states allegoric bodies have become a personification and collective symbol of the nation. Such allegories, both female and male, are popular around the world as part of the nation-building processes. In many Eastern European states such figures are labelled a national Mother figures, in many other countries as national Maids or ladies (Paasi 1996).

\section{Borders and territory}

For most political geographers borders are the key elements of territory that connect it to the practice of territoriality. Sack (1986) suggested that bounded spatial entities (regions) become territories only when their borders are used to control the mobility of human beings and availability of resources in these areas. Depending on bordering practices, borders may be inflexible or mobile, and may stretch across national space. Borders are thus contested, multilayered sets of social practices, institutions, symbols, and political objects (Paasi 2019). Both as institutions and symbols borders are unremittingly used as tools in the control of entry to territories and out of them.

The control function accentuated by Sack (1986) is exactly why borders are so critical in the making of territoriality and territory. However, a broader approach is needed to understand the complex role of memory in bordering practice in the context of state territoriality. It is thus beneficial to distinguish analytically two modalities of borders and bordering practice that help to understand why territorial borders are so persistent even in 
today's globalizing world and how these dividing lines are often so rapidly mobilized as tools in Othering, wars, conflicts, racism or xenophobia (Paasi 2013).

These modalities can be labelled as technical landscapes of social control and discursive landscapes of social power. Both modalities are historically and spatially contingent and serve the regulation and coherence of the state but their functions and meanings differ. The former resonates with state, sovereignty, citizenship, governance, security and control, the latter with nation, national identity, nationalism and memory. Both modalities expand the understanding of borders as mere lines on the ground. Technical landscapes control materializes borders and their regulation in relation to the mobility of bodies. As to the relation between territory, memory and nation, the discursive landscapes of social power are undoubtedly much more important. They become institutionalized along with the rise of state territory, and often draw on collective memories and symbols. Discursive landscapes namely consist of material national landscapes, nationally significant buildings with often remarkable symbolic value, generic or place specific memorials, national remembrances and nationalized events such as national flag and independence days, for example. The power of these landscapes draws on the fact that they position the symbolic meanings borders and bordering processes not only around the national territory but also convert them as part of the territory's traditions and contribute to the production and reproduction of collective identities and memories (Paasi 2013).

Particularly significant, almost universally used elements in national landscapes are military memorials and cemeteries that continuously maintain images of the divide between 'We' and the 'Other' or the Enemy. An impressive and ubiquitous example is the tomb of unknown soldier that is in use in numerous states and is usually a high-profile national monument. Figure 4 displays one notable example of such monuments, the 
eternal flame of the Unknown Soldier located at the Kremlin Wall in Moscow, dedicated to the Soviet soldiers killed during World War II. There are more than 3600 flames around the Russian state reminding of World War II. Such symbols are reminders of the territory and of the emotional bordering between us and the Other that can take place at various sites throughout the national territory and become part of the political technologies used in the reproduction of territory.

The discursive landscapes of social power are also typically reproduced in media and national socialization and they contribute to reproducing the existing hegemonic social order and typically epitomize space as undisputable by providing a specific 'reading' of societal values and norms. A more ubiquitous institution is the national legislation regarding borders, which is pervasive in the state but is particularly visible when executed in certain locations like border areas or airports (Paasi 2013, 2016). These illustrations display not merely the multifaceted sites of territorial borders and bordering but also that 'borders' exist at the same time at several spatial and time scales, actually fusing scales in various social and political practices and processes. While borders regularly mean different things to those living in border areas than to those living elsewhere in a state, discursive landscapes of borders effectively 'spread' borders and position citizens as part of the imagined national community (Paasi 1996). The fact that these landscapes receive their meanings in various forms of banal nationalism makes them very persistent in territorial meaning making (Billig 1995; Paasi 2016; Ashuri 2005). Likewise borders are often efficiently reproduced in movies, novels, poems, political cartoons and television programs. Such bordering also occurs in the control of language. 'Dubbing', for example, is in use in most non-English speaking European states. 'Dubbing' or 'revoicing', the replacement of the actor's voices with national languages, are popular in film industry and respectively in reterritorializing national languages. 


\section{Conclusions}

Recently emerged interest in territory and related publications in political geography, political science and political philosophy have highlighted the complexity of territory in the contemporary world, how the social relations of stateness permeate the everyday life in numerous ways and are critical in making territory as an effect (Painter 2006). Less attention has been paid how national identities and memories are a critical element in territorial state and nation building.

This chapter has scrutinized the somewhat neglected relation of state territory to the production and reproduction of nation and memory with the aim to better understand the enduring allure of territory in a world that is increasingly on the move and also to open some horizons and themes for future research agenda and comparative approaches. Nation and state are commonly conflated conceptually which leads to a naïve, typically state-led understanding of their complex relations, reflecting the traditional ideal of nationalism on the congruence of the state and the nation. This relation is always historically and spatially contingent: diverse perspectives on territory/territoriality are bound up with different conceptions of nation, state and homeland (Penrose 2002, Yiftachel 2002).

Contemporary states are characterized by a multifaceted practical, discursive and ideological apparatus through which the permeation of stateness into the everyday life occurs and that is also the medium for imagining the existence of a bounded national community. As Painter (2006) has shown the penetration of stateness continues during the whole life cycle of citizens, from giving birth and schooling, family life, and working life to dying. Narratives on national identity often combine selected elements to celebrate the state and nation and lean on collective memories and ideas of a shared common past, 
present and future. Both pasts and memories are contested and highly political. The state and its elites are frequently in a critical position in manufacturing specific views on the past. Apparatuses such as national education and national media are often mobilized in such work (Schlesinger 1991, Ashuri 2005). Especially national education has been a neglected area in geographic research on nationalism and could provide an interesting field for comparative studies on spatial socialization.

The world is transforming with an increasing pace and various forms of mobilities (migrants, goods, capital) across borders change the territorial relations in the globalizing world. Similarly the governance of territorial borders is ever more characterized by multilayered, diffuse and segmented modes of regulation and forms of authority stretching below and beyond the state territory and across borders. Simultaneously borders are increasingly mobile and can have multiple locations inside and outside of territories and as biometric borders 'located' in human bodies. New constellations of political, legal, and territorial practices suggest continuing tensions between national identities, memory, state security and emerging new global relationships. This will doubtless raise demands on new conceptual apparatuses and comparative empirical research for understanding them.

\section{References}

Althusser, L (1976) Ideologiset valtiokoneistot (orig. Positions). Jyväskylä: Vastapaino.

Anderson, B (1991) Imagined Communities. London: Verso.

Antonsich, M (2009 On territory, the nation-state and the crisis of the hyphen. Progress in Human Geography 33 (6), 789 - 806. 
Ashuri, T (2005) The nation remembers: national identity and shared memory in television documentaries. Nations and Nationalism, 11 (3), 423-442.

Billig, M (1995) Banal Nationalism. London: Sage.

Bloom, W (1990) Personal Identity, National Identity and International Relations. Cambridge: Cambridge University Press.

Cox, K R (2002) Political Geography: Territory, State and Society. Oxford: Blackwell.

Delaney, D (2005) Territory: A Short Introduction. Oxford: Blackwell.

Drozdzewski, D, De Nardi, S and E Waterton (eds. 2016) Memory, Place and Identity: Commeration and Remembrance of War and Conflict. London: Routledge.

Elden, S (2013) The Birth of Territory. Chicago: Chicago University Press.

Entrikin, N J (2002) Democratic place-making and multiculturalism. Geografiska Annaler B, $84(1), 19-25$.

Forest, B and J Johnson (2002) Unraveling the threads of history: Soviet-Era monuments and Post-Soviet national identity in Moscow. Annals of the Association of American Geographers 92 (3), 524-547. 
Giddens, A (1984) The Constitution of Society. Cambridge: Polity.

Gottmann, J (1973) The Significance of Territoriality. Charlottesville, VA: University Press of Virginia.

Ochoa Espejo P (2018) Why borders do matter morally: the role of place in immigrants' rights. Constellations 25 (1), 71-86.

Gellner, E (1983) Nations and Nationalism. Oxford: Blackwell.

Gellner, D (1998) Mediakulttuuri (orig. Media Culture). Tampere: Vastapaino.

Guibernau, M (2007) The Identity of Nations. Cambridge: Polity.

Hacking, I (1999) The Social Construction of What? Cambridge, MA: Harvard University Press.

Halbwachs, M (1992) On Collective Memory. Chicago and London: The University of Chicago Press.

Hassner, P (1997) Osbtinate and obsolete: non-territorial transnational forces versus the European territorial state. In Tunander, O, Baev, P and V.I. Einagel (eds.) Geopolitics of the Post-Wall Europe. London: Sage, pp. 45-58 
Hobsbawm, E (1983) Introduction: Inventing traditions. In E. Hobsbawm and T. Ranger (Eds.), The Invention of Tradition. Cambridge: Cambridge University Press, pp. 1-14

Hodgin, K and Radstone, S (eds. 2012). Memory, History, Nation: Contested Pasts. London (UK): Transaction Publishers.

Jessop, B (2008) State Power: A Strategic-Relational Approach. Cambridge: Polity

Johnson, N (1995) Cast in stone: monuments, geography, and nationalism. Environment and Planning D: Society and Space 13 (1), 51-65

Johnson, $\mathrm{N}$ (2011) The contours of memory in post-conflict societies: enacting public remembrance of the bomb in Omagh, Northern Ireland. Cultural Geographies 19 (2), 237258.

Jokinen, M (2018) "Ei voi puhua ja vitsailla kuin 1980- ja 1990-luvuilla" - mielipide ja huumori vievät vankilaan myös Euroopassa. Suomen Kuvalehti 5.8.2018.

Kaiser, R J (2002) Homeland making and the territorialization of national identity. In Conversi, D (ed) Ethnonationalism in the Contemporary World. London Routledge, 229247

Kislik, D (1983) V.I. Lenin Memorial Places in the USSR. Moscow: Raduga Publishers. 
Kivimäki, V (2013) Battled Nerves: Finnish Soldiers' War Experience, Trauma, and Military Psychiatry 1941-44. Tampere: Juvenes Print.

Knight, D B (1982) Identity and Territory: Geographical Perspectives on Nationalism and Regionalism. Annals of the Association of American Geographers 72 (4), 514-531

Koch, N (2013) Sport and soft authoritarian nation-building. Political Geography 32, 42-51

Koch, N (2016) 'Spatial socialization': understanding the state effect geographically. Nordia Geographical Publications 44 (4), 29-35.

Koch, $\mathrm{N}$ and Paasi A (2016) Banal Nationalism 20 years on: Re-thinking, re-formulating and re-contextualizing the concept. Political Geography 54, 1-6.

Kolers, A (2009) Land, Conflict, and Justice: A Political Theory of Territory. Cambridge: Cambridge University Press.

Kuzio, T (2002) History, memory and nation-building in the Post-Soviet colonial space. Nationalities Papers 30 (2), 241-264.

Mann, M (1996) Nation-states in Europe and other continents: diversifying, developing, not dying. In Balakrishnan, G (ed.) Mapping the Nation. London: Verso.

Mellor, R.E.H. (1989) Nation, State and Territory. London: Routledge 
Meusburger, P, Heffernan, M and Wunder E (ed. 2011) Cultural Memories: The Geographical Point of View. Berlin: Springer

Miller, D (1995). On Nationality. Oxford: Clarendon Press.

Murphy, A B (1990) Historical justification for territorial claims. Annals of the Association of American Geographers 80(4), 531-548.

Murphy, A B (2013). Territory's continuing allure. Annals of the Association of American Geographers 103 (5), 1212-1226

Paasi, A (1996) Territories, Boundaries and Consciousness. The Changing Geographies of the Finnish-Russian Border. Chichester: John Wiley.

Paasi, A (1999) Nationalizing Everyday Life: Individual and Collective identities as Practice and Discourse. Geography Research Forum 19, 4-21

Paasi, A (2003): Territory. In Agnew, J, Mitchell, K and G Toal (eds). A Companion to Political Geography. Blackwell, Oxford 2003, pp. 109-122.

Paasi, A (2013) Borders and border crossings. In Johnson, N, Schein, R and J Winders (editors): A New Companion to Cultural Geography. London: Wiley-Blackwell. pp. 478493. 
Paasi, A (2016) Dancing on the graves: independence, hot/banal nationalism and the mobilization of memory. Political Geography 54, 21-31.

Paasi, A (2019). Borderless worlds and beyond: challenging the state centric cartographies. In Paasi, A, Prokkola, E-K, J Saarinen \& K Zimmerbauer (eds.). Borderless Worlds for Whom? Ethics, Moralities, Mobilities. London, Routledge, pp. 21-36.

Paasi, A, Harrison, J and Jones, M (eds. 2018) Handbook on the Geographies of Territories and Regions. London: Elgar

Painter, J (2006) Prosaic geographies of stateness. Political Geography 25, 752-774.

Painter, J (2010) Rethinking territory. Antipode 45 (5), 1090--1118

Penrose, J (2002) Nations, states and homelands: territory and territoriality in nationalist thought. Nations and Nationalism 8 (3) 277-297

Poli, S (2007) The Denationalization of Sport: De-ethnicization of the Nation and Identity Deterritorialization. Sports in Society 10 (4), 646-661

Sack, B (1986) Human Territoriality: Its Theory and History. Cambridge: Cambridge University Press.

Sassen, S (2009) Bordering Capabilities Versus Borders: Implications for National Borders. Michigan Journal of International Law 30 (3), 567-597. 
Schlesinger, P (1991). Media, State and Nation: Political Violence and Collective Identities. London: Sage.

Smith, A D (1991). National Identity. Reno: University of Nevada Press.

Soja, E (1971) Political Organization of Space. Washington, D.C.: Association of American Geographers, Commission on College Geography,

Storey, D (2012) Territories: The Claiming of Space. London: Routledge.

Storey, D (2018) Territory and Territoriality. In Paasi, A, Harrison, J and M Jones (eds.). Handbook on the Geographies of Regions and Territories. Cheltenham: Elgar.

Taylor PJ and Flint C (2000) Political Geography. Harlow: Prentice Hall.

Tervo, M. (2002) Sports, 'race' and the Finnish national identity in Helsingin Sanomat in the early twentieth century. Nations and Nationalism 8 (3) 335-356

Till, K and Kuusisto-Arponen, A-K (2015) Towards responsible geographies of memory: complexities of place and the ethics of remembering. Erdkunde 69 (4), 291-306.

Williams C and Smith A.D (1983) The national construction of social space. Progress in Human Geography 7 (4), 502-518 
Wimmer, A (2018) Nation-Building. Princeton: Princeton University Press.

Yiftachel, $O$ (2002) Territory as the kernel of the nation: space, time and nationalism in Israel/Palestine. Geopolitics 7(2), 215-248. 


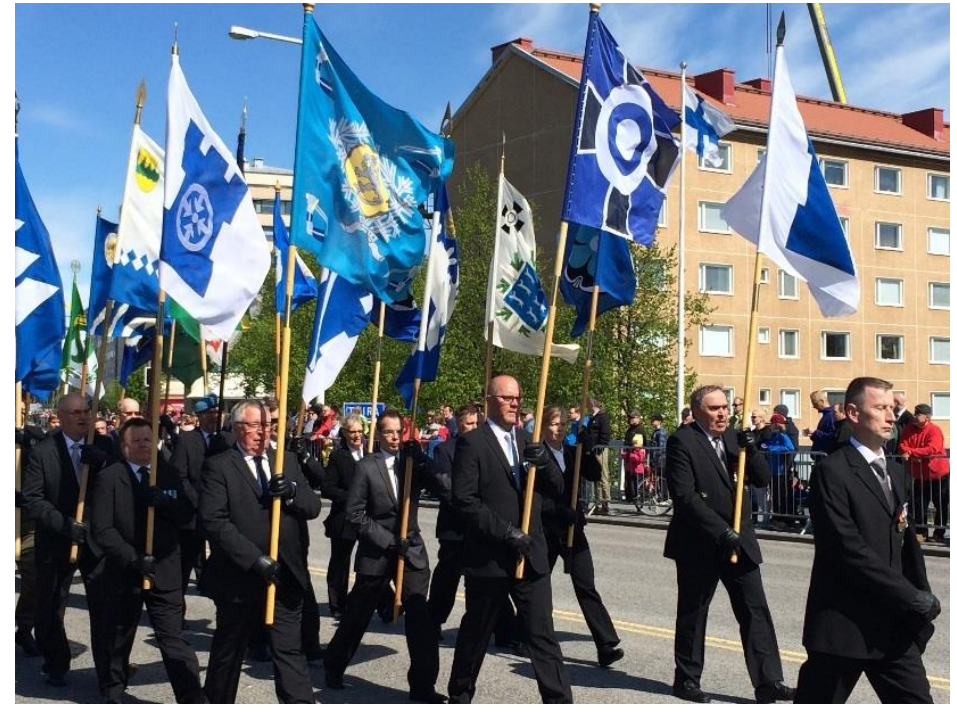

Figure 1. Veteran organizations in the National Parade on the Flag Day of the Finnish Defense Forces in 2015 (Photo: Anssi Paasi)
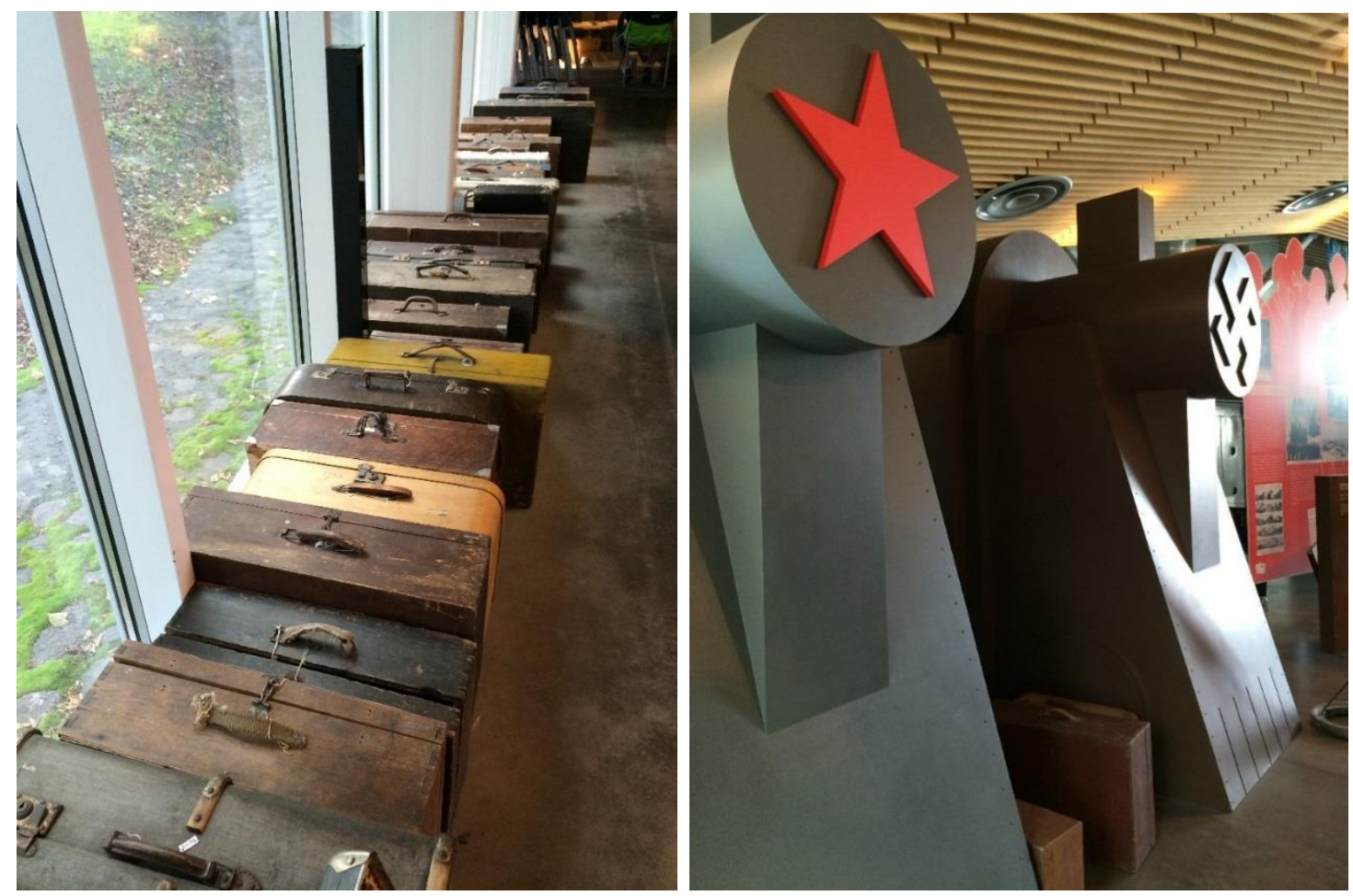

Figure 2. The Museum of Occupation in Tallinn, Estonia (Photos: Anssi Paasi) 


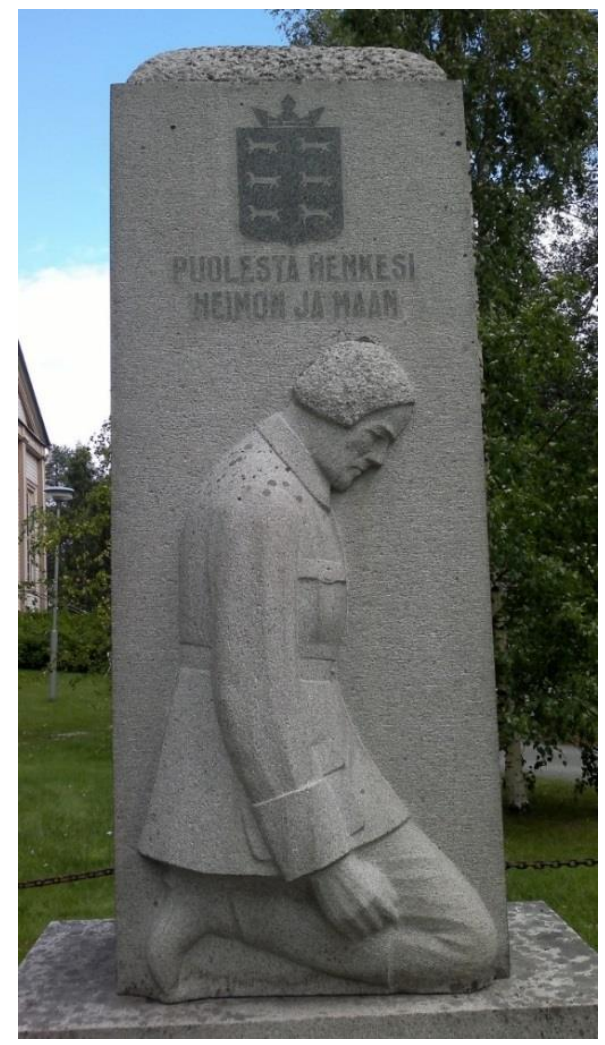

Figure 3. Memorial of the Civil War, labelled as Freedom War, in Sotkamo, Finland (Photo: Anssi Paasi)

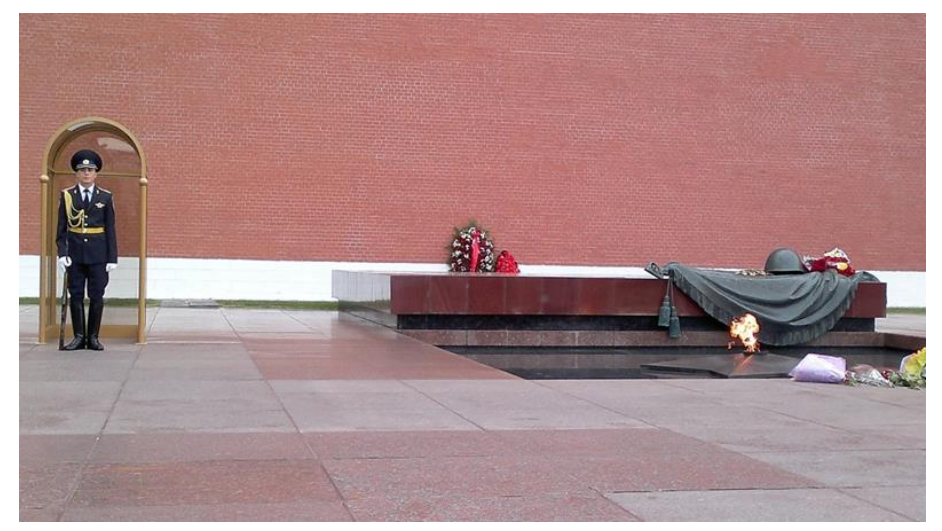

Figure 4. 'Eternal flame' at the Memorial of the Unknown Soldier at Kremlin, Moscow (Photo: Anssi Paasi) 